\title{
Faktor Yang Mempengaruhi Keberlanjutan Minat Pengguna Dalam Menggunakan Aplikasi mHealth Melalui Variabel Satisfaction
}

Submitted Date:

7 April 2021

Accepted Date:

27 April 2021

\author{
Vania Katherine Hermawan \\ Universitas Kristen Satya Wacana Salatiga \\ katherinehrmwn10@gmail.com \\ Eristia Lidia Paramita* \\ Universitas Kristen Satya Wacana Salatiga \\ eristia.paramita@uksw.edu
}

\section{Suggested Citation:}

Zagita, T. C., Handayani, P. W., \& Budi, N. F. A. (2019). Analysis of Factors Affecting the Loyalty of Using Online Health Services : Case Study of Alodokter. 279-284.

\section{Abstract:}

The use of internet and smartphone has evolved. The rapid growth of innovation in technology allows them to become a high-functioning service provider through many of the applications available to help out humans fulfilling their needs. People demand quick and instant service provision, including health service. Applications based on mHealth technology are made to serve that demand. This research aims to examine the effects of intervening variables such as perceived usefulness, perceived ease of use, trust in application, and satisfaction on consumers' continuance intention to use mHealth technology. This research employs a quantitative method to assess primary data samples taken from the users of Halodoc health service application in Java. The results of this research show that the trust and perceived usefulness variables do not significantly affect consumers' continuance usage intention. Only the perceived ease of use and satisfaction variables yield a significant impact on consumers' continuance usage intention. Hopefully, these results can be a valuable insight for PT Media Dokter Investama to enhance their service to attract more mHealth technology users to use Halodoc.

Keywords: mHealth Technology, Continuance Usage Intention, Perceived Ease of Use, Perceived Usefulness, Satisfaction

Abstrak:

Internet dan smartphone tak lagi hanya digunakan sebagai sarana komunikasi namun smartphone kini berevolusi melalui aplikasi-aplikasi penyedia layanan yang mempermudah aktivitas manusia, salah satunya adalah jasa penyedia layanan kesehatan. Aplikasi yang menyediakan layanan kesehatan menjadi jawaban dari keinginan masyarakat di era globalisasi dimana masyarakat dunia terutama di Indonesia menginginkan semuanya serba cepat dan praktis. Tujuan dari penelitian ini adalah untuk mengetahui pengaruh perceived usefulness, perceived ease of use, trust in application dan satisfaction sebagai variabel intervening terhadap continuance intention to use mHealth technology. Penelitian ini berjenis kuantitatif dengan pengguna aplikasi Halodoc yang berada di Pulau Jawa sebagai sampel data primer. hasil dari penelitian ini membuktikan bahwa variabel perceived usefulness dan trust berpengaruh tidak signifikan terhadap continuance usage intention. Sedangkan variabel perceived ease of use dan satisfaction berpengaruh signifikan terhadap continuance usage intention. Hasil dari penelitian ini diharapkan dapat bermanfaat juga bagi PT. Media Dokter Investama untuk dapat meningkatkan performa serta kualitas pelayanan guna memikat semakin banyaknya pengguna mHealth technology di Indonesia.

Kata Kunci: Teknologi mHealth, Keberlanjutan Penggunaan, Persepsi Kemudahan, Persepsi Kemanfaatan, Kepuasan

JEL Classification: M31 
Latar Belakang

Indonesia menempati posisi ke - 6 sebagai negara dengan pengguna smartphone terbanyak di dunia (Herdyanto, 2019). Dalam perkembangannya, smartphone tidak lagi hanya digunakan sebagai sarana komunikasi melalui media sosial, namun smartphone berevolusi melalui aplikasi-aplikasi penyedia layanan yang mempermudah aktivitas manusia termasuk dalam bidang kesehatan. Aplikasi yang menyediakan layanan kesehatan menjadi jawaban dari keinginan masyarakat di era globalisasi dimana masyarakat dunia terutama di Indonesia menginginkan semuanya serba cepat dan praktis. Perpaduan antara smartphone dengan aplikasi ini, membuat gaya hidup individu telah berubah (Pai \& Alathur, 2019). Jumlah pengguna layanan kesehatan digital (mHealth) yang meningkat secara signifikan membuktikan bahwa mHealth digemari masyarakat (Ulya, 2019). Ada banyak faktor yang mampu mendorong seseorang untuk menggunakan aplikasi yang berhubungan dengan kesehatan karena fungsi dasar dari aplikasi kesehatan adalah untuk membantu seseorang untuk mengelola kesehatannya (Chen \& Linang, 2017) seperti perceived usefulness, perceived ease of use, trust in application, dan satisfaction.

Perceived usefulnes dalam penelitian Zagita et al. (2019) bermakna bahwa ketika ekspektasi user terhadap teknologi yang digunakan terkonfirmasi, kemungkinan besar user dapat menggunakan teknologi tersebut secara efektif dan dapat melihat teknologi tersebut berguna baginya. Cho (2016) menyatakan bahwa jika pengguna dapat mencapai tujuan dengan cara yang diharapkan melalui teknologi, maka kegunaan yang dirasakan akan meningkat. Hasil penelitian (Zagita et al., 2019; Bangkara \& Mimba, 2016; Sulistiyarini, 2012) menyatakan bahwa perceived usefulness berpengaruh positif terhadap minat menggunakan sebuah teknologi. Bertolak belakang dengan hasil penelitian Ismail (2016) yang menunjukkan bahwa perceived usefulness tidak berpengaruh terhadap minat menggunakan sebuah teknologi. Ketika user merasa tidak memerlukan banyak sumber daya untuk dapat mempelajari teknologi baru, maka user akan menganggap bahwa teknologi tersebut memang berguna (Zagita et al., 2019). Perceived ease of use dapat diukur melalui seberapa mudah sistem atau teknologi tersebut digunakan. (Kumala et al., 2020). Dalam penelitian Zhao \& Wang (2020) dan Ismail (2016), perceived ease of use memiliki pengaruh yang signifikan terhadap prceived usefulness. Hasil dari penelitian (Bangkara \& Mimba, 2016; Sulistiyarini, 2012; Ismail, 2016; Kumala et al., 2020 dan Priambodo \& Prabawani, 2016) menyatakan bahwa perceived ease of use berpengaruh positif terhadap minat penggunaan layanan teknologi.

Trust in application diukur melalui application's reputation atau reputasi dari aplikasi itu sendiri. Albrecht et al. (2015), dalam penelitiannya mengatakan bahwa pengguna cenderung menentukan kepercayaannya berdasarkan penyaringan rating dari pengguna yang lain dari aplikasi yang sama melalui rating yang ada di app store, playstore atau sumber lain seperti blog atau website. Logikanya, orang akan mau menggunakan aplikasi kesehatan online jika aplikasi tersebut memiliki rating review atau memiliki reputasi yang baik sehingga dapat membuat user percaya dan akhirnya mau menggunakan aplikasi tersebut, hal ini sudah dibuktikan melalui penelitian yang dilakukan oleh Zagita et al. (2019). Pada penelitian Zagita et al. (2019) application's reputation berpengaruh positif terhadap trust in application dan continuance usage intention dalam menggunakan aplikasi kesehatan online. Penelitian yang dilakukan oleh (Sugara \& Dewantara, 2017; Irianti \& Adi, 2017) juga menunjukkan bahwa kepercayaan mempengaruhi minat untuk menggunakan sebuah teknologi.

Zagita et al. (2019) menjelaskan bahwa dalam konteks layanan kesehatan online, tingginya tingkat kepuasan pengguna dipengaruhi oleh semakin mudah penggunaan dan banyaknya manfaat yang diperoleh melalui layanan tersebut. Jika pengguna merasakan pengalaman yang menyenangkan ketika menggunakan teknologi dan melihat bahwa teknologi tersebut berguna, maka taraf kepuasan pengguna terhadap teknologi tersebut akan berpengaruh secara positif dan berpotensi untuk menjadi pemeran utama dalam mempengaruhi keberlanjutan minat terhadap teknologi tersebut (Hartanto et al., 2020). Menurut Suhendro (2017) kepuasan diukur melalui kualitas sistem dan kualitas informasi yang diberikan. Melalui penelitian (Zagita et al., 2019; Sugara \& Dewantara, 2017; Hartanto et al., 2020) membuktikan bahwa kepuasan memberikan pengaruh positif terhadap keberlanjutan minat menggunakan teknologi. Bahkan Hartanto et al. (2020) dalam penelitiannya disebutkan bahwa kepuasan sangat mempengaruhi niat kelanjutan penggunaan teknologi. Penelitian yang dilakukan oleh (Maryanto, 2019) membuktikan bahwa satisfaction berhasil berfungsi sebagai variabel yang memediasi antara perceived usefulness dan customer loyalty dalam konteks aplikasi ojek online. Melalui penelitiannya, Logiawan \& Subagio (2014) dan Darwin et al. (2014) membuktikan bahwa customer satisfaction berpengaruh terhadap customer loyalty dalam ranah kuliner dan asuransi kesehatan. Kemudian Valentina (2020) dalam penelitiannya yang menggunakan aplikasi fintech OVO sebagai obyek penelitian membuktikan bahwa esatisfaction berpengaruh terhadap e-loyalty. 
Penelitian ini merupakan modifikasi dari penelitian Zagita et al. (2019) yang berbicara mengenai aplikasi layanan kesehatan atau mHealth. Modifikasi dilakukan karena ada research gap yang ingin dijawab melalui penelitian ini berupa research limitation dari penelitian Peprah et al. (2019) untuk meneliti tentang informasi kesehatan seperti apa yang dicari oleh pengguna aplikasi mHealth. Kemudian penelitian ini juga akan menjawab keterbatasan penelitian dari Pai \& Alathur (2019) untuk menggunakan variabel perceived ease of use dan trust untuk mengukur signifikansi dan varians dalam niat penggunaan. Dan yang terakhir karena adanya inkonsistensi hasil dari pengaruh variabel perceived usefulness dan ease of use yang saling mempengaruhi. Pada penelitian Zhao \& Wang (2020) ease of use berpengaruh positif terhadap perceived usefulness. Namun hal ini bertolak belakang dengan hasil penelitian To et al. (2019) dan Zagita et al. (2019) yang menunjukkan bahwa ease of use tidak berpengaruh positif terhadap perceived usefulness. Peneliti juga menambahkan variabel satisfaction sebagai variabel intervening yang di adopsi dari penelitian Kaium et al. (2019) yang mempengaruhi continuance usage intention. Variabel satisfaction ditambahkan karena menurut Kaium et al. (2019), satisfaction merupakan salah satu faktor yang memiliki pengaruh positif terhadap continuance usage intention layanan mHealth.

Jika pada penelitian sebelumnya obyek penelitian atau aplikasi mHealth yang digunakan Zagita et al. (2019) adalah Alodokter, pada penelitian ini aplikasi mHealth yang digunakan adalah Halodoc. Halodoc adalah aplikasi yang bergerak di bidang layanan telekonsultasi kesehatan yang menawarkan aneka layanan kesehatan seperti pengiriman obat, konsultasi secara online dengan sarana video call, tes laboratorium, direktorat rumah sakit dan dokter serta penjadwalan (Wakhida \& Sanaji, 2020). Kesehatan merupakan salah satu bagian penting dalam kehidupan manusia (Prasanti \& Indriani, 2018) terlebih di saat pandemi seperti sekarang ini. Terbukti bahwa jumlah kunjungan user layanan kesehatan jarak jauh seperti Halodoc meningkat sebesar 600 persen di masa pandemi (Arlinta, 2020). Hal ini dikarenakan tak sedikit masyarakat yang takut berobat ke rumah sakit atau klinik dikarenakan takut akan potensi terpapar virus Covid-19 (Perkasa, 2020). Penelitian ini bertujuan untuk mengetahui pengaruh perceived usefulness, perceived ease of use, trust in application dan satisfaction sebagai variabel intervening terhadap continuance intention to use mHealth technology. Manfaat dari penelitian ini adalah untuk menambah kajian literatur mengenai mHealth technology di Indonesia. Hasil dari penelitian ini diharapkan dapat bermanfaat juga bagi PT. Media Dokter Investama untuk dapat meningkatkan performa serta kualitas pelayanan guna memikat semakin banyaknya pengguna mHealth technology di Indonesia.

\section{Tinjauan Pustaka}

\section{Persepsi Kegunaan}

Definisi perceived usefulness menurut Faradila \& Soesanto (2016) adalah persepsi yang dirasakan oleh pengguna tentang seberapa besar manfaat yang akan diperoleh. Teknologi tersebut mampu memberikan manfaat bila digunakan jika bisa berfungsi sebagaimana mestinya (Hidayat, 2020). Wang et al. (2016) mengatakan bahwa perceived usefulness dapat dirasakan oleh konsumen ketika teknologi yang diadopsi dapat digunakan dimana saja dan kapan saja. Perceived usefulness pada penelitian ini diukur dengan 3 dimensi yaitu health consciousness, doctor's information quality dan doctor's service quality yang sebelumnya telah dijelaskan dibagian pendahuluan. Selain 3 dimensi yang telah disebutkan, peneliti menambahkan dimensi perceived usefulness berdasarkan penelitian Wang et al. (2016) yaitu penghematan waktu dan kenyamanan.

H1: Perceived usefulness berpengaruh terhadap continuance usage intention

H2: Perceived usefulness berpengaruh terhadap satisfaction

\section{Persepsi Kemudahan}

Persepsi kemudahan menurut Faradila \& Soesanto (2016) adalah sebagai seberapa besar pengguna dapat percaya bahwa dengan menggunakan sebuah sistem akan mempermudah. Perceived ease of use juga dapat diartikan sebagai kemudahan penggunaan teknologi tanpa perlu mengeluarkan banyak usaha dan terbebas dari kesulitan (Perangin-angin et al., 2016). Oentario et al. (2017) beranggapan bahwa jika pengguna merasa teknologi tersebut mudah digunakan, maka pengguna akan mau menggunakannya dan begitu pula sebaliknya. Persepsi kemudahan dalam penelitian ini memiliki batas pengukuran dimensi sebesar seberapa mudah sistem atau teknologi tersebut digunakan, mudah dipelajari, terkendali, serta jelas dan dapat dipahami. 
H3: Perceived ease of use berpengaruh terhadap perceived usefulness

H4: Perceived ease of use berpengaruh terhadap satisfaction

H5: Perceived ease of use berpengaruh terhadap continuance usage intention

\section{Kepercayaan}

Menurut Kotler \& Keller (2016) kepercayaan adalah keinginan untuk dapat mengandalkan orang lain dalam melakukan sesuatu. Albrecht et al. (2015) menjelaskan bahwa kepercayaan dan reliability adalah aspek yang harus diingat karena aplikasi kesehatan harus mengandung konten yang kredibel dan valid, serta dapat berfungsi sesuai harapan pengguna. Yang terpenting adalah bagaimana aplikasi kesehatan tersebut dapat menangani data medis para pasiennya yang memiliki tingkat sensitivitas tinggi (Albrecht et al., 2015). Pihak penyedia teknologi harus dapat menjamin keamanan dan kerahasiaan alat yang digunakan oleh pengguna untuk mendapatkan kepercayaan pengguna (Yogananda, 2017). Jika keamanan terhadap e-service ditingkatkan dan ditekankan pada setiap transaksi, dapat meningkatkan trust dari konsumen sehingga interaksi antara konsumen dan perusahaan akan meningkat (Sujadi, 2010). Dimensi yang digunakan untuk mengukur e-trust adalah application's reputation, memuat informasi yang kredibel dan valid, integritas, kompetensi, loyalty dan openess. H6: Trust in application berpengaruh terhadap continuance usage intention

\section{Kepuasan}

Menurut Kotler \& Keller (2009), kepuasan digambarkan sebagai perasaan kecewa atau senang yang dihasilkan dari perbandingan performa produk terhadap ekspektasi yang dimiliki oleh konsumen. Kepuasan menurut Sidharta \& Suzanto (2015) adalah persepsi pengguna terhadap kualitas barang atau jasa yang sesuai dengan harapan konsumen, dengan demikian dapat dikatakan bahwa jasa tersebut baik untuk digunakan dan begitu pula sebaliknya. Dimensi e-satisfaction dapat diukur dengan kualitas sistem, kualitas informasi, mudahnya penggunaan dan banyaknya manfaat yang dirasakan oleh user melalui layanan tersebut.

H7: Satisfaction berpengaruh terhadap continuance usage intention

H8: Satisfaction berpengaruh terhadap trust in application

H9: Perceived usefulness dan perceived ease of use bersama-sama mempengaruhi continuance usage intention melalui satisfaction

\section{Keinginan Menggunakan Kembali}

Continuance usage intention digunakan dalam penelitian ini karena konteks penelitian ini mengacu pada seseorang yang sudah pernah menggunakan dan akan menggunakan kembali kemudian hari (Hidayat, 2020). Continuance usage intention menurut Hidayat (2020) dapat dilihat sebagai indikator seberapa besar keinginan seseorang untuk tetap menggunakan, rutin menggunakan, memiliki keyakinan bahwa teknologi yang digunakan sudah tepat dan memiliki keinginan untuk merekomendasikan kepada orang lain. Dimensi pengukuran continuance usage intention yang digunakan pada penelitian ini adalah keinginan konsumen untuk tetap menggunakan, keinginan konsumen untuk rutin menggunakan, keyakinan bahwa ini merupakan penggunaan yang tepat dan keinginan konsumen untuk merekomendasikan kepada orang lain.

\section{Metode Penelitian}

Desain penelitian yang digunakan adalah analisis deskriptif (Shidiq \& Widodo, 2018). Jenis penelitian ini menggunakan metode kuantitatif. Tipe penelitian yang digunakan oleh peneliti adalah explanatory research, yaitu penelitian yang menjelaskan posisi variabel-variabel yang akan diteliti dan hubungan antar variabel, serta melakukan pengujian hipotesis yang telah dirumuskan (Silaen \& Prabawani, 2019). Melalui penelitian ini, peneliti akan mengukur bagaimana perceived usefulness, peceived ease of use, trust in application dapat mempengaruhi continuance usage intention dengan satisfaction sebagai variabel intervening. Populasi yang terlibat dalam penelitian ini adalah seluruh pengguna aplikasi mHealth khususnya Halodoc di Pulau Jawa. Teknik pengambilan sampel yang digunakan adalah purposive sampling. Peneliti menggunakan data primer. Data primer yang tersebut akan dikumpulkan melalui kuesioner online menggunakan google form. Skala instrumen yang digunakan untuk mengukur variabel dalam penelitian ini adalah linkert. Data primer yang telah diperoleh akan diolah dan dianalisis menggunakan teknik Structural Equation Model (SEM). 
Gambar 1. Model Penelitian

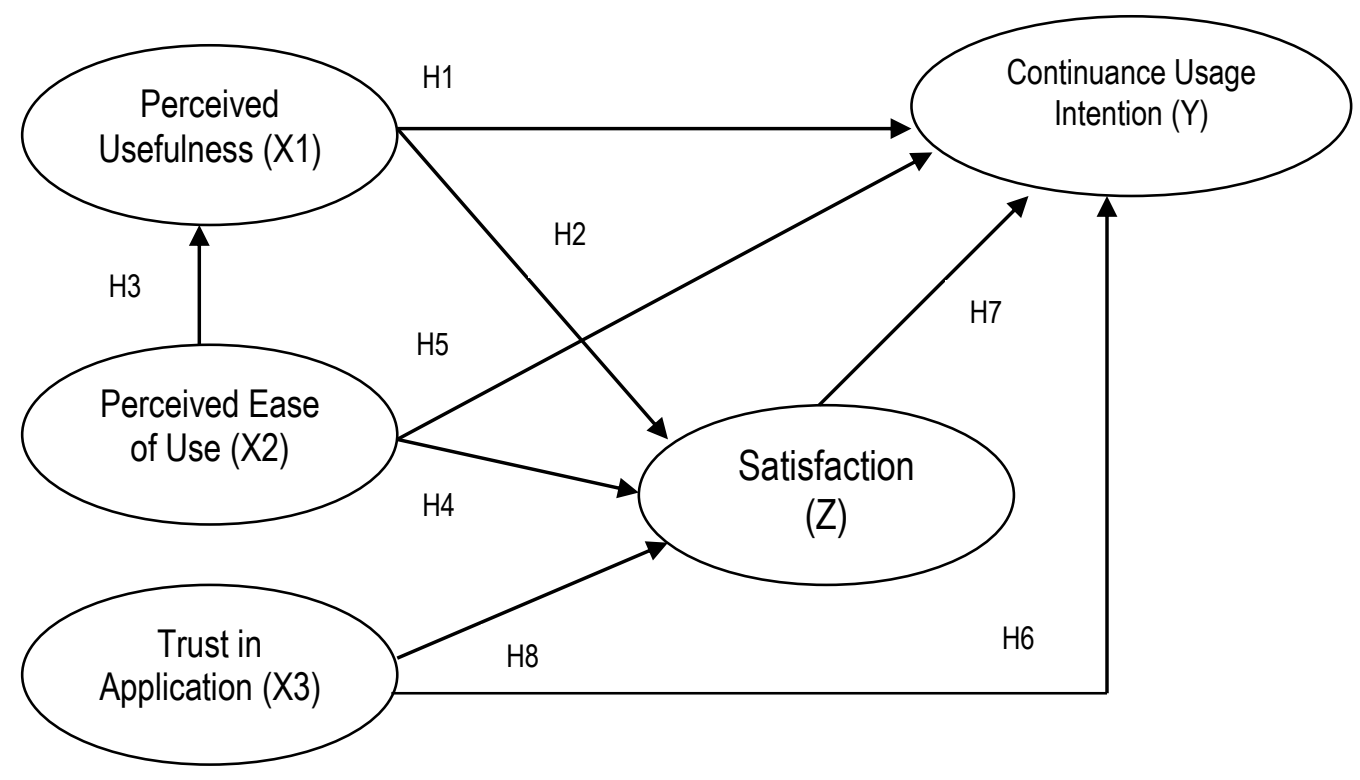

Sumber: Modifikasi dari penelitian (Kaium et al., 2019; Pai \& Alathur, 2019; Zagita et al., 2019)

Hasil

Data primer yang berhasil terkumpul sebanyak 201 responden. Data primer tersebut kemudian diolah untuk mengetahui deskripsi usia, jenis kelamin dan pekerjaan responden. Berdasarkan deskripsi variabel usia diperoleh usia rata-rata sebesar 22,766 tahun, lalu diperoleh usia minimum sebesar 16 tahun dan usia maksimum sebesar 52 tahun. Lalu Berdasarkan deskripsi variabel jenis pekerjaan didominasi oleh pelajar/mahasiswa sebesar 77,1. Rata-rata domisili terbanyak diperoleh responden di sekitar jawa tengah khususnya Kota Semarang dan Kabupaten Semarang, Kota Salatiga, dan Kota Surakarta. Sepuluh informasi atau fitur terbanyak yang digunakan oleh responden pada penelitian ini adalah jasa layanan dokter umum yang kemudian disusul dengan informasi seputar virus covid-19, informasi apotek atau toko kesehatan terdekat, artikel kesehatan, jasa layanan dokter spesialis kulit, informasi rumah sakit terdekat, jasa layanan dokter gigi, jasa layanan dokter penyakit dalam, jasa layanan psikolog klinis dan dokter hewan. Hal ini menjawab keterbatasan penelitian Peprah et al. (2019) mengenai informasi kesehatan seperti apa yang dicari oleh pengguna aplikasi mHealth. Untuk menjawab research limitation dari penelitian Peprah et al. (2019) untuk meneliti tentang informasi kesehatan seperti apa yang dicari oleh pengguna aplikasi mHealth. Selengkapnya dapat dilihat pada lampiran 1.

Penelitian ini menggunakan analisis model persamaan struktural atau SEM (Structural Equation Model) SEM merupakan metode statistik yang dapat digunakan untuk pendekatan konfirmatori dalam melakukan analisis multivariat dari teori struktural yang terjadi. Pada umumnya SEM dibagi menjadi dua bagian yaitu, measurement model (model pengukuran) dan structural model (model persamaan struktural) (Byrne, 1998). Tujuan dari model pengukuran adalah untuk menggambarkan indikator yang dapat digunakan dalam instrumen pengukuran variabel laten. Uji validitas dan reliabilitas kembali dilakukan setelah pengumpulan data primer berakhir. Uji validitas menunjukkan tingkat ketepatan antara data yang sesungguhnya terjadi dengan data yang dikumpulkan oleh peneliti pada objek penelitian (Sugiyono, 2019). Menurut Hair et al. (2016), validitas didefinisikan sebagai sejauh mana penelitian itu akurat. Nilai loading factor yang memenuhi yaitu lebih besar dari 0,7 . Hasil uji validitas dapat dilihat pada lampiran 2.

Selanjutnya, diperoleh masing-masing nilai r-hitung dengan kriteria nilai loading factor lebih besar dari 0,7 dapat disimpulkan semua indikator penelitian pada variabel laten ini dinyatakan valid. Reliabilitas adalah alat untuk mengukur suatu kuesioner yang merupakan indikator dari variabel atau konstruknya. Suatu kuesioner bisa dikatakan reliabel jika jawaban seseorang terhadap pernyataan adalah konsisten atau stabil dari waktu ke waktu (Abdillah \& Hartono, 2015). 
Tabel 1. Uji Reliabilitas

\begin{tabular}{lll} 
Variabel & Cronbach's Alpha & Keterangan \\
Perceived Usefulness & 0,88 & Reliabel \\
Perceived Ease of Use & 0,76 & Reliabel \\
Trust in Applications & 0,77 & Reliabel \\
Satisfaction & 0,85 & Reliabel \\
Continuance Usage Intention & 0,82 & Reliabel \\
\hline
\end{tabular}

Sumber: Data primer diolah (2021)

Pada uji reliabilitas variabel di atas diperoleh masing-masing nilai r-hitung dengan kriteria nilai reliabel sebesar 0,6 dapat disimpulkan semua variabel laten dalam penelitian ini dinyatakan reliabel. Uji Reliabilitas dan Validitas dilakukan pada butir-butir pernyataan dalam kuesioner untuk melihat apakah pernyataan-pernyataan tersebut reliabel dan valid untuk digunakan dalam penelitian ini. Uji validitas dan Reliabilitas menggunakan data primer yang didapatkan dari 30 responden dengan $r$ tabel sebesar 0,3494 dan $a=5$ persen. Hasil dari uji reliabilitas menyatakan bahwa pernyataan-pernyataan yang ada pada semua variabel yang digunakan, reliabel karena nilai Cronbach's Alpha nya lebih besar daripada r tabel. Namun pada uji validitas, ditemukan adanya satu butir pernyataan yang tidak valid pada variabel persepsi manfaat dengan nilai yang didapati adalah 0,333 yang mana lebih kecil daripada $r$ tabel 0,3494. Pernyataan yang invalid tersebut berbunyi "Saya merasa dengan menggunakan aplikasi Halodoc lebih efektif daripada menggunakan layanan dokter konvensional (offline). Dari semula total 19 indikator yang digunakan untuk mengukur persepsi manfaat, berkurang satu indikator yang tidak valid. Indikator yang tidak valid tersebut kemudian dihapuskan. Secara keseluruhan digunakan 54 pernyataan dalam penelitian ini.

Untuk mengetahui apakah model yang dibuat didasarkan pada data yang sesuai model teori atau tidak, maka perlu adanya acuan indeks kecocokan model. Nilai Goodness of Fit yang diperoleh sebesar 0,080 . Nilai $\mathrm{R}^{2}$ sebesar 0,080 dapat dikatakan memiliki nilai yang tinggi dalam menjelaskan data dalam penelitian ini, sehingga secara keseluruhan, model yang digunakan dapat dikatakan valid. Nilai $Q^{2}$ didapatkan melalui rumus $Q^{2}=1-(1$ $\left.-0,120^{2}\right)\left(1-0,120^{2}\right)\left(1-0,027{ }^{2}\right)\left(1-0,030{ }^{2}\right)\left(1-0,036{ }^{2}\right)$ yang memiliki hasil 0,515 , sehingga model struktural yang digunakan dapat dikatakan relevan. Dari keenam uji kesesuaian model yang telah dilakukan, lima uji dinyatakan baik. Dengan demikian dapat disimpulkan uji kesesuaian model ini terpenuhi dan model layak digunakan. Berdasarkan prinsip Rule of Thumb, jika satu atau dua dari enam uji Goodness of Fit dinyatakan baik atau terpenuhi, maka model dapat dinyatakan layak (Latan, 2013). Kriteria pengujian hipotesis penelitian ini yaitu dengan memperhatikan $t$-values antar variabel kemudian dibandingkan dengan nilai kritisnya (t-tabel). Dalam hal ini nilai kritis untuk ukuran sampel besar $(n>30)$ dengan taraf $a=0,05$ yaitu sebesar 1,96 . Dengan ini hubungan yang memiliki t-values > 1,96 dapat dikatakan signifikan (Hair et al., 2016).

Tabel 2. Uji Hipotesis

\begin{tabular}{llll} 
Hipotesis & Koefisien Regresi & Nilai Signifikansi & Keterangan \\
\hline $\mathrm{PU} \rightarrow$ RI & 0,059 & 0,120 & Tidak signifikan \\
$\mathrm{PU} \rightarrow$ STS & 0,59 & 0,039 & Signifikan \\
$\mathrm{PEOU} \rightarrow$ PU & 0,88 & 0,026 & Signifikan \\
$\mathrm{PEOU} \rightarrow$ STS & 0,33 & 0,043 & Signifikan \\
$\mathrm{PEOU} \rightarrow \mathrm{RI}$ & 0,32 & 0,030 & Signifikan \\
$\mathrm{TRST} \rightarrow \mathrm{RI}$ & 0,25 & 0,120 & Tidak signifikan \\
$\mathrm{STS} \rightarrow \mathrm{RI}$ & 0,43 & 0,027 & Signifikan \\
STS $\rightarrow$ TRST & 0,90 & 0,027 & Signifikan \\
PU+PEOU*STS $\rightarrow$ RI & 0,39 & 0,090 & Tidak Signifikan
\end{tabular}

Sumber: Data primer diolah (2021)

Berdasarkan uji hipotesis yang telah dilakukan dengan tingkat signifikansi sebesar $5 \%$ maka dapat disimpulkan bahwa diperoleh nilai koefisien regresi sebesar 0,059 artinya variabel Perceived Usefulness berpengaruh positif terhadap variabel Continuance Usage Intention. Dengan nilai signifikansi sebesar 0,120 maka 0,120>0,05 sehingga dapat disimpulkan variabel Perceived Usefulness berpengaruh tidak signifikan terhadap variabel Continuance Usage Intention. Jadi, hipotesis pertama pada penelitian ini ditolak.

Diperoleh nilai koefisien regresi sebesar 0,59 artinya variabel Perceived Usefulness berpengaruh positif terhadap variabel Satisfaction. Dengan nilai signifikansi sebesar 0,039 maka 0,039<0,05 sehingga dapat 
disimpulkan variabel Perceived Usefulness berpengaruh signifikan terhadap variabel Satisfaction. Dapat disimpulkan bahwa hipotesis kedua pada penelitian ini diterima.

Diperoleh nilai koefisien regresi sebesar 0,88 artinya variabel Perceived Ease of Use berpengaruh positif terhadap variabel Perceived Usefulness. Dengan nilai signifikansi sebesar 0,026 maka 0,026 < 0,05 sehingga dapat disimpulkan variabel Perceived Ease of Use berpengaruh signifikan terhadap variabel Perceived Usefulness. Dapat disimpulkan bahwa hipotesis ketiga pada penelitian ini diterima.

Diperoleh nilai koefisien regresi sebesar 0,33 artinya variabel Perceived Ease of Use berpengaruh positif terhadap variabel Satisfaction. Dengan nilai signifikansi sebesar 0,043 maka 0,043<0,05 sehingga dapat disimpulkan variabel Perceived Ease of Use berpengaruh signifikan terhadap variabel Satisfaction. Dapat disimpulkan bahwa hipotesis keempat pada penelitian ini diterima.

Diperoleh nilai koefisien regresi sebesar 0,32 artinya variabel Perceived Ease of Use berpengaruh positif terhadap variabel Continuance Usage Intention. Dengan nilai signifikansi sebesar 0,030 maka 0,030<0,05 sehingga dapat disimpulkan variabel Perceived Ease of Use berpengaruh signifikan terhadap variabel Continuance Usage Intention. Dapat disimpulkan bahwa hipotesis kelima pada penelitian ini diterima.

Diperoleh nilai koefisien regresi sebesar 0,25 artinya variabel Trust in Applications berpengaruh positif terhadap variabel Continuance Usage Intention. Dengan nilai signifikansi sebesar 0,120 maka 0,120>0,05 sehingga dapat disimpulkan variabel Trust in Applications berpengaruh tidak signifikan terhadap variabel Continuance Usage Intention. Jadi, dapat disimpulkan bahwa hipotesis keenam pada penelitian ini ditolak.

Diperoleh nilai koefisien regresi sebesar 0,43 artinya variabel Satisfaction berpengaruh positif terhadap variabel Continuance Usage Intention. Dengan nilai signifikansi sebesar 0,027 maka 0,027 < 0,05 sehingga dapat disimpulkan variabel Satisfaction berpengaruh signifikan terhadap variabel Continuance Usage Intention. Dapat disimpulkan bahwa hipotesis ketujuh pada penelitian ini diterima.

Diperoleh nilai koefisien regresi sebesar 0,90 artinya variabel Satisfaction berpengaruh positif terhadap variabel Trust in Applications. Dengan nilai signifikansi sebesar 0,027 maka 0,027 $<0,05$ sehingga dapat disimpulkan variabel Satisfaction berpengaruh signifikan terhadap variabel Trust in Applications. Dapat disimpulkan bahwa hipotesis kedelapan pada penelitian ini diterima.

Diperoleh nilai koefisien regresi sebesar 0,39 artinya variabel Perceived Usefulness dan Perceived Ease of Use berpengaruh positif terhadap variabel Continuance Usage Intention melalui Satisfaction. Dengan nilai signifikansi sebesar 0,090 maka 0,090 >0,05 sehingga dapat disimpulkan variabel Perceived Usefulness dan Perceived Ease of Use berpengaruh tidak signifikan terhadap variabel Continuance Usage Intention melalui Satisfaction. Jadi dapat disimpulkan bahwa hipotesis kesembilan pada penelitian ini ditolak.

\section{Pembahasan}

\section{Pengaruh Persepsi Kegunaan dan Keinginan Menggunakan Kembali}

Hasil penelitian ini menunjukkan bahwa variabel perceived usefulness berpengaruh tidak signifikan terhadap variabel continuance usage intention. Jika dilihat dari hasil koefisien regresi sebesar 0,059 variabel perceived usefulness memiliki hubungan korelasi yang lemah terhadap variabel continuance usage intention. Hubungan negatif ini dapat dilihat dari nilai signifikansi sebesar 0,120 yang lebih besar dari 0,05 . Sehingga dapat disimpulkan bahwa variabel perceived usefulness berpengaruh tidak signifikan terhadap variabel continuance usage intention. Hasil hipotesis ini sejalan dengan penelitian Ismail (2016) yang menyatakan bahwa perceived usefulness berpengaruh tidak signifikan terhadap continuance usage intention. Lima dimensi perceived usefulness yang digunakan yaitu health consciousness, doctor's information quality, doctor's service quality, penghematan waktu, dan kenyamanan belum dapat membawa variabel perceived usefulness untuk memberikan pengaruh positif terhadap variabel continuance usage intention.

\section{Pengaruh Persepsi Kegunaan dan Kepuasan}

Hasil penelitian ini menunjukkan bahwa variabel perceived usefulness berpengaruh positif terhadap variabel satisfaction. Jika dilihat dari hasil koefisien regresi sebesar 0,59 variabel perceived usefulness memiliki hubungan korelasi yang lemah terhadap variabel satisfaction karena angkat koefisen regresi tidak mendekati angka satu. Hubungan positif ini dapat dilihat dari nilai signifikansi sebesar 0,039 yang lebih kecil dari 0,05. Sehingga dapat disimpulkan bahwa variabel perceived usefulness berpengaruh positif dan signifikan terhadap 
variabel satisfaction. Hasil hipotesis ini sejalan dengan penelitian Ashghar \& Nurlatifah (2020); Pambudi (2020); Wiwoho (2019) yang menyatakan bahwa variabel perceived usefulness berpengaruh positif dan signifikan terhadap variabel satisfaction. Lima dimensi perceived usefulness yang digunakan yaitu health consciousness, doctor's information quality, doctor's service quality, penghematan waktu, dan kenyamanan dapat membawa variabel perceived usefulness untuk memberikan pengaruh positif terhadap variabel satisfaction.

\section{Pengaruh Persepsi Kemudahan dan Persepsi Kegunaan}

Hasil penelitian ini menunjukkan bahwa variabel Perceived ease of use berpengaruh positif terhadap variabel perceived usefulness. Jika dilihat dari hasil koefisien regresi sebesar 0,88 variabel perceived ease of use memiliki hubungan korelasi yang kuat terhadap variabel perceived usefulness karena angkat koefisen regresi tersebut mendekati angka satu. Hubungan positif ini dapat dilihat dari nilai signifikansi sebesar 0,026 yang lebih kecil dari 0,05 . Sehingga dapat disimpulkan bahwa variabel perceived ease of use berpengaruh positif dan signifikan terhadap variabel perceived usefulness. Hasil hipotesis ini sejalan dengan penelitian Anjelina (2018); Wakhida \& Sanaji (2020); Zhao \& Wang (2020) yang membuktikan bahwa variabel perceived ease of use berpengaruh terhadap positif dan signifikan terhadap variabel perceived usefulness. Batas pengukuran dimensi seberapa mudah sistem tekonologi dapat digunakan, mudah dipelajari, terkendali, serta jelas dan dapat dipahami telah tercapai sehingga variabel perceived ease of use berhasil memberikan pengaruh yang positif terhadap variabel perceived usefulness. Hipotesis ini sekaligus menjawab kesenjangan penelitian Zhao \& Wang (2020) yang menyatakan bahwa ease of use berpengaruh positif terhadap perceived usefulness. Namun bertolak belakang dengan hasil penelitian To et al. (2019) dan Zagita et al. (2019) yang menunjukkan bahwa ease of use berpengaruh tidak signifikan terhadap perceived usefulness. Hasilnya, penelitian ini sejalan dengan penelitian Zhao \& Wang (2020).

\section{Pengaruh Persepsi Kemudahan dan Kepuasan}

Hasil penelitian ini menunjukkan bahwa variabel Perceived ease of use berpengaruh positif terhadap variabel satisfaction. Jika dilihat dari hasil koefisien regresi sebesar 0,33 variabel perceived ease of use memiliki hubungan korelasi yang lemah terhadap variabel satisfaction karena angka koefisen regresi tersebut tidak mendekati angka satu. Hubungan positif ini dapat dilihat dari nilai signifikansi sebesar 0,043 yang lebih kecil dari 0,05 . Sehingga dapat disimpulkan bahwa variabel perceived ease of use berpengaruh positif dan signifikan terhadap variabel satisfaction. Hasil hipotesis ini sejalan dengan penelitian Ashghar \& Nurlatifah (2020); Pambudi (2020); Rizan et al. (2019) yang membuktikan bahwa variabel perceived ease of use berpengaruh terhadap positif dan signifikan terhadap variabel satisfaction. Batas pengukuran dimensi seberapa mudah sistem tekonologi dapat digunakan, mudah dipelajari, terkendali, serta jelas dan dapat dipahami telah tercapai sehingga variabel perceived ease of use berhasil memberikan pengaruh yang positif terhadap variabel satisfaction.

\section{Pengaruh Persepsi Kemudahan dan Keinginan Menggunakan Kembali}

Hasil penelitian ini menunjukkan bahwa variabel Perceived ease of use berpengaruh positif terhadap variabel continuance usage intention. Jika dilihat dari hasil koefisien regresi sebesar 0,32 variabel perceived ease of use memiliki hubungan korelasi yang lemah terhadap variabel continuance usage intention karena angka koefisen regresi tersebut tidak mendekati angka satu. Hubungan positif ini dapat dilihat dari nilai signifikansi sebesar 0,030 yang lebih kecil dari 0,05 . Sehingga dapat disimpulkan bahwa variabel perceived ease of use berpengaruh positif dan signifikan terhadap variabel continuance usage intention. Hasil hipotesis ini sejalan dengan penelitian (Hamid et al., 2016; Hidayat, 2020; Susanti, 2015; Lee et al., 2017; Sindhu Singh, 2018; Teo et al., 2019) yang membuktikan bahwa variabel perceived ease of use berpengaruh terhadap positif dan signifikan terhadap variabel continuance usage intention. Batas pengukuran dimensi seberapa mudah sistem tekonologi dapat digunakan, mudah dipelajari, terkendali, serta jelas dan dapat dipahami telah tercapai sehingga variabel perceived ease of use berhasil memberikan pengaruh yang positif terhadap variabel continuance usage intention.

\section{Pengaruh Kepercayaan dan Keinginan Menggunakan Kembali}

Hasil penelitian ini menunjukkan bahwa variabel trust in application berpengaruh positif terhadap variabel continuance usage intention. Jika dilihat dari hasil koefisien regresi sebesar 0,25 variabel trust in application memiliki hubungan korelasi yang lemah terhadap variabel continuance usage intention karena angka koefisen regresi tersebut tidak mendekati angka satu. Hubungan positif ini dapat dilihat dari nilai signifikansi sebesar 0,120 yang lebih besar dari 0,05 . Sehingga dapat disimpulkan bahwa variabel trust in application berpengaruh 
positif dan signifikan terhadap variabel continuance usage intention. Hasil hipotesis ini sejalan dengan penelitian Darwin et al, (2014) yang membuktikan bahwa variabel trust in application berpengaruh tidak signifikan terhadap variabel continuance usage intention. Responden merasakan bahwa dimesi yang digunakan untuk mengukur etrust yang terdiri dari application's reputation, memuat informasi yang kredibel dan valid, integritas, kompetensi, loyal dan openness belum dirasa memuaskan sehingga variabel kepercayaan belum dapat memberikan pengaruh positif terhdap variabel penggunaan kembali.

\section{Pengaruh Kepuasan dan Keinginan Menggunakan Kembali}

Hasil penelitian ini menunjukkan bahwa variabel satisfaction berpengaruh positif terhadap variabel continuance usage intention. Jika dilihat dari hasil koefisien regresi sebesar 0,43 variabel satisfaction memiliki hubungan korelasi yang lemah terhadap variabel continuance usage intention karena angka koefisen regresi tersebut tidak mendekati angka satu. Hubungan positif ini dapat dilihat dari nilai signifikansi sebesar 0,027 yang lebih kecil dari 0,05 . Sehingga dapat disimpulkan bahwa variabel satisfaction berpengaruh positif dan signifikan terhadap variabel continuance usage intention. Hasil hipotesis ini sejalan dengan penelitian Rahman \& Dewantara (2017); Ulya (2013); Muliawan \& Pambudi (2019); Hasanah (2020); Irianti \& Adi (2017) yang membuktikan bahwa variabel satisfaction berpengaruh positif dan signifikan terhadap variabel continuance usage intention. Dimensi esatisfaction yang dapat diukur melalui kualitas sistem, kualitas informasi, mudahnya penggunaan dan banyaknya manfaat yang dirasakan oleh user melalui aplikasi Halodoc dapat terpenuhi sehingga variabel satisfaction dapat memberikan pengaruh positif terhadap variabel continuance usage intention. Namun, pengaruh positif variabel satisfaction terhadap continuance usage intention menyebabkan inkonsistensi dari hasil penelitian ini karena jika dilihat dari dimensi yang telah dicapai, konsumen merasa puas terhadap banyaknya manfaat yang diberikan oleh aplikasi Halodoc yang seharusnya dapat membawa variabel perceived usefulness untuk memberikan pengaruh positif terhadap variabel continuance usage intention.

\section{Pengaruh Kepuasan dan Kepercayaan}

Hasil penelitian ini menunjukkan bahwa variabel Variabel satisfaction berpengaruh positif terhadap variabel trust in application. Jika dilihat dari hasil koefisien regresi sebesar 0,90 variabel satisfaction memiliki hubungan korelasi yang kuat terhadap variabel trust in application karena angka koefisen regresi tersebut mendekati angka satu. Hubungan positif ini dapat dilihat dari nilai signifikansi sebesar 0,027 yang berarti lebih kecil dari 0,05. Sehingga dapat disimpulkan bahwa variabel satisfaction berpengaruh positif dan signifikan terhadap variabel trust in application. Hasil hipotesis ini sejalan dengan penelitian Adji \& Semuel (2014); Bernarto et al. (2019); Sa'adah; Jahizatus (2011); Valentina (2020) yang membuktikan bahwa variabel satisfaction berpengaruh terhadap positif dan signifikan terhadap variabel trust in application. Jika dilihat dari definisi variabel satisfaction, konsumen merasa bahwa ekspektasinya terhadap kualitas layanan aplikasi Halodoc sudah tercapai sehingga menimbulkan rasa percaya konsumen terhadap jasa layanan yang ditawarkan oleh aplikasi Halodoc.

\section{Pengaruh Persepsi Kemudahan, Persepsi Kegunaan dan Keinginan Menggunakan Kembali Melalui Kepuasan}

Hasil penelitian ini menunjukkan bahwa variabel Perceived usefulness dan perceived ease of use berpengaruh positif terhadap variabel continuance usage intention melalui satisfaction. Jika dilihat dari hasil koefisien regresi sebesar 0,39 variabel Perceived Usefulness dan Perceived Ease of Use memiliki hubungan korelasi yang lemah terhadap variabel continuance usage intention melalui satisfaction karena angka koefisen regresi tersebut tidak mendekati angka satu. Hubungan positif ini dapat dilihat dari nilai signifikansi sebesar 0,090 yang lebih besar dari 0,05. Sehingga dapat disimpulkan bahwa variabel variabel Perceived Usefulness dan Perceived Ease of Use berpengaruh tidak signifikan terhadap variabel continuance usage intention melalui satisfaction.

\section{Kesimpulan}

Perceived Usefulness berpengaruh signifikan terhadap variabel satisfaction. Hal ini menunjukkan bahwa semakin baik persepsi kegunaan yang dirasakan oleh pengguna, maka pengguna akan merasakan kepuasan saat menggunakan aplikasi Halodoc. Perceived Ease Of Use berpengaruh signifikan terhadap variabel Perceived Usefulness. Hal ini menunjukkan bahwa semakin tinggi tingkat persepsi kemudahan yang dirasakan oleh konsumen, semakin tinggi pula persepsi kemanfaatan yang akan dirasakan oleh konsumen. Perceived 
Ease Of Use berpengaruh signifikan terhadap variabel satisfaction. Persepsi kemudahan juga terbukti dapat mempengaruhi kepuasan, jadi semakin tinggi nilai persepsi kemudahan yang dirasakan, maka semakin tinggi pula kepuasan yang dirasakan oleh pengguna. Perceived Ease Of Use berpengaruh signifikan terhadap variabel Continuance Usage Intention. Hasil ini menunjukkan bahwa salah satu faktor yang menyebabkan keinginan pengguna untuk menggunakan kembali aplikasi Halodoc adalah tingginya persepsi kemudahan yang dirasakan oleh pengguna. Satisfaction berpengaruh signifikan terhadap variabel Continuance Usage Intention. Hal ini menujukkan bahwa salah satu faktor yang menyebabkan pengguna ingin menggunakan kembali layanan aplikasi Halodoc adalah karena pengguna merasa puas dengan layanan yang diberikan oleh aplikasi Halodoc. Satisfaction berpengaruh signifikan terhadap variabel Trust in Applications. Hal ini berarti semakin tinggi nilai kepuasan terhadap layanan yang diberikan oleh aplikasi Halodoc, maka semakin tinggi pula kepercayaan pengguna terhadap aplikasi Halodoc.

Perceived Usefulness berpengaruh tidak signifikan terhadap variabel Continuance Usage Intention, Trust in Applications berpengaruh tidak signifikan terhadap variabel Continuance Usage Intention. Hal ini menunjukkan bahwa keinginan untuk menggunakan kembali sebuah jasa layanan tidak selalu berpatok pada persepsi kegunaan dan kepercayaan yang dirasakan oleh pengguna jasa tersebut, namun keinginan untuk menggunakan kembali sebuah jasa layanan dapat dipengaruhi oleh faktor-faktor yang lainnya.

Meskipun secara parsial variabel persepsi kemanfaatan dapat berpengaruh terhadap variabel keinginan untuk menggunakan kembali, namun secara simultan variabel persepsi kegunaan dan persepsi kemanfaatan melalui variabel kepuasan tidak berhasil berpengaruh positif terhadap keinginan untuk menggunakan kembali jasa aplikasi Halodoc. Dapat dikatakan bahwa sebagai variabel yang menjembatani persepsi kegunaan dan persepsi kemudahan, kepuasan belum mampu membawa persepsi kemudahan dan persepsi kegunaan untuk dapat berpengaruh positif terhadap keinginan untuk menggunakan kembali layanan aplikasi Halodoc.

Apabila dilihat dari hasil penlitian ini, ditemukan bahwa secara keseluruhan, pengguna Halodoc yang menjadi responden pada penelitian ini sudah memberikan nilai yang baik terhadap aplikasi. Hal ini dapat dilihat dari rata-rata statistic deskriptif sebesar 4,30 yang berarti sudah menunjukkan hampir seluruh indikator dalam penelitian ini mendapatkan peringkat yang baik. Namun, masih ada beberapa indikator yang belum berada di peringkat yang baik. Oleh karena itu, saran yang dapat diberikan kepada Halodoc adalah:

Meningkatkan kualitas informasi yang diberikan oleh dokter atau tenaga medis lainnya melalui aplikasi Halodoc kepada pengguna aplikasi Halodoc sehingga pengguna aplikasi merasakan kepercayaan dan dapat mendorong pengguna aplikasi untuk terus menggunakan aplikasi Halodoc. Hal ini dapat dilakukan dengan memberikan informasi yang jelas, tepat dan faktual kepada pengguna aplikasi. Alangkah baiknya aplikasi Halodoc lebih memperhatikan kredibilitas tenaga medis yang bersinggungan langsung dengan pengguna.

Meningkatkan keamanan karena pada rata-rata deskriptif kuesioner dalam hal keamanan memang diklasifikasi tinggi namun memiliki nilai terendah dalam satu lingkup variabel sehingga Halodoc sebaiknya lebih lagi meningkatkan keamanan yang mereka buat seperti menambahkan kode verifikasi di setiap transaksi, lebih menjaga keamanan data pribadi hingga Riwayat penyakit pengguna aplikasi.

Saran kepada peneliti selanjutnya dapat berfokus pada keterbatasan yang ada pada penelitian ini yaitu kurangnya ragam domisili responden karena hanya berpusat di Pulau Jawa dan mayoritas responden hanya berasal dari Jawa Tengah. Atas hal tersebut, peneliti selanjutnya dapat memperluas daerah jangkauan responden sehingga hasil yang didapatkan diharapkan akan lebih maksimal dan lebih beragam. Kemudian saran yang lain adalah mengganti teknik analisis atau piranti uji untuk melihat apakah hasil yang didapatkan akan sama atau berbeda dengan penelitian ini. Saran yang terakhir ialah memodifikasi penelitian ini sehingga dapat menambah literatur studi tentang mobile health application di masa yang akan datang. 


\section{Daftar Pustaka}

Abdillah, W., \& Hartono, J. (2015). Abdillah, W., \& Hartono, J. (2015). Partial Least Square (PLS): alternatif structural equation modeling (SEM) dalam penelitian bisnis. Peneribit Andi.

Adji, J., \& Semuel, H. (2014). Pengaruh Satisfaction dan Trust Terhadap Minat Pembelian di Starbucks The Square Surabaya. Jurnal Strategi Pemasaran, 2(1), 1-10. http://publication.petra.ac.id/index.php/manajemen-pemasaran/article/view/1394

Albrecht, U.-V., Pramann, O., \& von Jan, U. (2015). Medical Apps -The Road To Trust. European Journal for Biomedical Informatics, 11(03), 7-12. https://doi.org/10.24105/ejbi.2015.11.3.3

Anjelina, A. (2018). Persepsi Konsumen Pada Penggunaan E-Money. Journal of Applied Managerial Accounting, 2(2), 219-231. https://doi.org/10.30871/jama.v2i2.934

Arlinta, D. (2020, August 22). Layanan Kesehatan Jarak Jauh Meningkat 600 Persen di Masa Pandemi. Kompas.Com.

Ashghar, S. A., \& Nurlatifah, H. (2020). Analisis Pengaruh Perceived Ease of Use , Perceived Usefulness , dan Perceived Risk terhadap Keinginan Membeli Kembali melalui e-Trust dan s-Satisfaction. Jurnal Al Azhar Indonesia, 1(1).

Bangkara, R. P., \& Mimba, N. P. S. H. (2016). Pengaruh Perceived Usefulness Dan Perceived Ease of Use Pada Minat Penggunaan Internet Banking Dengan Attitude Toward Using Sebagai Variabel Intervening. E-Jurnal Akuntansi Universitas Udayana, 16(3), 2408-2434.

Bernarto, I., Wilson, N., \& Suryawan, I. N. (2019). Pengaruh Website Design Quality , Service Quality , Trust dan Satisfaction Jurnal Manajemen Indonesia Pengaruh Website Design Quality, Service Quality, Trust dan Satisfaction Terhadap Repurchase Intention (Studi Kasus : tokopedia.com). Jurnal Manajemen Indonesia, 19(1), 80-90. https://doi.org/10.25124/jmi.v19i1.1987

Byrne, B. (1998). Structural equation modeling with LISREL, PRELIS, and SIMPLIS: Basic concepts, applications, and programming.

Chen, M.-F., \& Linang, N.-P. (2017). Incorporation of health consciousness into the technology readiness and acceptance model to predict app download and usage intentions.

Cho, J. (2016). The Impact of Post-Adoption Beliefs on The Continued Use of Health Apps. International Journal of Medical Informatics, 87, 75-83.

Darwin, S., Kunto, S., Si, S., Sc, M., Pemasaran, P. M., Petra, U. K., \& Siwalankerto, J. (2014). Analisis Pengaruh Kualitas Layanan Terhadap Loyalitas Pelanggan Dengan Kepuasan dan Kepercayaan Pelanggan Sebagai Variabel Intervening Pada Asuransi Jiwa Manulife Indonesia - Surabaya. 2(1), 1-12.

Faradila, R. S. N., \& Soesanto, H. (2016). Analisis Pengaruh Persepsi Kemudahan Penggunaan dan Persepsi Manfaat terhadap Minat Beli dengan Kepercayaan Sebagai Variabel Intervening (Studi pada Pengunjung Toko Online berrybenka.com di Kalangan Mahasiswa Universitas Diponegoro). Jurnal Studi Manajemen Organisasi, 13(2), 149. https://doi.org/10.14710/jsmo.v13i2.13406

Hair, J., Hult, T., Ringle, C., \& Sarstedt, M. (2016). A Primer on Partial Least Squares Structural Equation Modeling (PLS-SEM). In SAGE (Second). SAGE. 
Hamid, A. A., Razak, F. Z. A., Bakar, A. A., \& Abdullah, W. S. W. (2016). The Effects of Perceived Usefulness and Perceived Ease of Use on Continuance Intention to Use E-Government. Procedia Economics and Finance, 35(October 2015), 644-649. https://doi.org/10.1016/s2212-5671(16)00079-4

Hartanto, Y., Michael, Sanjaya, T., \& Windranata, T. (2020). Pengaruh Game Berbasis Coding Terhadap Keberlanjutan Minat Belajar Programming Siswa di Batam , Indonesia. 6(1).

Hasanah, U. (2020). Analisis continuance use intention pada situs jejaring sosial instagram dengan menggunakan Expectation-Confirmation Model (ECM). In UIN Syarif Hidayatullah. Fakultas Sains dan Teknologi Universitas Islam Negeri Syarif Hidayatullah Jakarta.

Herdyanto, A. (2019, April 30). 10 Negara Ini Punya Jumlah Pengguna Smartphone Terbanyak di Dunia! Idntimes.Com. https://www.idntimes.com/tech/gadget/abraham-herdyanto/negara-dengan-jumlahpengguna-smartphone-terbesar $/ 10$

Hidayat, R. (2020). New Trend in New Normal,Factors InfluencingContinuance Intention to Use Video Conferencing. Jurnal IImiah PoliBisnis, 12.

Irianti, N. D., \& Adi, S. W. (2017). Pengaruh Kepercayaan, Kemudahan, Kepuasan dan Resiko Terhadap Minat Pembeli Untuk Menggunakan Sistem E-Commerce. Journal of Chemical Information and Modeling, 53(9), 1689-1699.

Ismail, H. A. (2016). Intention to Use Smartphone Through Perceived Compatibility, Perceived Usefulness, and Perceived Ease of Use. Jurnal Dinamika Manajemen, 7(1), 1. https://doi.org/10.15294/jdm.v7i1.5748

Kaium, A., Bao, Y., Alam, M. Z., \& Hoque, M. R. (2019). Understanding continuance usage intention of mHealth in a developing country An empirical investigation. 14(2), 251-272. https://doi.org/10.1108/JJPHM-06-20190041

Kotler, P., \& Keller, K. L. (2009). Marketing Management (13th ed) (13th ed.).

Kotler, P., \& Keller, K. L. (2016). Marketing Management (Global Edition) 15th Edition. Pearson.

Kumala, D. C., Pranata, J. W., \& Thio, S. (2020). Pengaruh Perceived Usefulness, Perceived Ease of Use, Trust, Dan Security Terhadap Minat Penggunaan Gopay Pada Generasi X Di Surabaya. Jurnal Manajemen Perhotelan, 6(1), 19-29. https://doi.org/10.9744/jmp.6.1.19-29

Latan, H. (2013). Model Persamaan Struktural Teori dan Implementasi AMOS 21.0 (Cetakan Ke). Alfabeta.

Lee, E. Y., Lee, S. B., \& Jeon, Y. J. J. (2017). Factors influencing the behavioral intention to use food delivery apps. Social Behavior and Personality, 45(9), 1461-1474. https://doi.org/10.2224/sbp.6185

Logiawan, Y., \& Subagio, H. (2014). ANALISA CUSTOMER VALUE TERHADAP CUSTOMER LOYALTY DENGAN CUSTOMER SATISFACTION SEBAGAI VARIABEL INTERVENING PADA RESTORAN BANDAR DJAKARTA SURABAYA. Manajemen Pemasaran Petra, 2(1), 1-11.

Maryanto, R. H. (2019). Pengaruh Perceived Usefulness Terhadap Customer Loyalty yang Dimediasi Oleh Customer Satisfaction dan Dimoderasi Perceived Ease-of- Use Pada Pengguna Aplikasi Grab di Surabaya. Universitas Ciputra.

Muliawan, D., \& Pambudi, R. (2019). Analisis Penerimaan dan Penggunaan Berkelanjutan Terhadap Teknologi Cloud Storage Pada Alumni Unika Atma Jaya. 11(Vol 11 No 1 (2019): Prosiding Working Papers Series In Management).

Oentario, Y., Harianto, A., \& Irawati, J. (2017). Pengaruh Usefulness, Ease of Use, Risk Terhadap Intentionto Buy Onlinepatisserie Melalui Consumer Attitude Berbasis Media Sosial Di Surabaya. Jurnal Manajemen 
Pemasaran, 11(1), 26-31. https://doi.org/10.9744/pemasaran.11.1.26-31

Pai, R. R., \& Alathur, S. (2019). Determinants of individuals' intention to use mobile health: insights from India. Transforming Government: People, Process and Policy, 13(3-4), 306-326. https://doi.org/10.1108/TG-042019-0027

Pambudi, R. (2020). Pengaruh Promotion, Perceived Ease Of Use, Perceived Usefulness Terhadap Customer Satisfaction Pengguna Transaksi GoPay (Studi Pada Pengguna Transaksi GoPay Di Kabupaten Kebumen). STIE Putra Bangsa.

Peprah, P., Abalo, E. M., Agyemang-duah, W., Gyasi, R. M., Reforce, O., Nyonyo, J., Amankwaa, G., Amoako, J., \& Kaaratoore, P. (2019). Knowledge, attitude, and use of mHealth technology among students in Ghana : A university-based survey. 0,1-11.

Perangin-angin, W. A., Respati, A. D., \& Kusumawati, M. D. (2016). Pengaruh Perceived Usefulness Dan Perceived Ease of Use Terhadap Attitude Toward Using E-Faktur. Jurnal Riset Ekonomi Dan Manajemen, 16(2), 307. https://doi.org/10.17970/jrem.16.1602010.id

Perkasa, G. (2020, August 6). Peran Penting Platform Layanan Kesehatan di Masa Pandemi. Kompas.Com. https://lifestyle.kompas.com/read/2020/08/06/183504620/peran-penting-platform-layanan-kesehatan-dimasa-pandemi?page=all

Prasanti, D., \& Indriani, S. S. (2018). PENGEMBANGAN TEKNOLOGI INFORMASI DAN KOMUNIKASI DALAM SISTEM E-HEALTH "alodokter.com." Jurnal Sosioteknologi, 17(1), 93-103. https://doi.org/10.5614/sostek.itbj.2018.17.1.9

Priambodo, S., \& Prabawani, B. (2016). Pengaruh Persepsi Manfaat, Persepsi Kemudahan Penggunan, Dan Persepsi Risiko Terhadap Minat Menggunakan Layanan Uang Elektronik (Studi Kasus Pada Masyarakat Di Kota Semarang). Jurnal IImu Administrasi Bisnis, 5(2), 127-135.

Rahman, A., \& Dewantara, R. Y. (2017). Pengaruh Kemudahan Penggunaan dan Kemanfaatan Teknologi Informasi Terhadap Minat Menggunakan Situs Jual Beli Online. Jurnal Admonistrasi Bisnis, 52(1), 1-7. http://ezproxy.leedsbeckett.ac.uk/login?url=http://search.ebscohost.com/login.aspx?direct=true\&db=edseur \&AN=edseur..9200111.BibliographicResource.1000086006687\&site=eds-live\&scope=site

Rizan, M., Haro, A., \& Rahmadhina, B. (2019). Pengaruh Perceived Ease of Use dan Service Quality Terhadap Customer Satisfaction dengan Trust Sebagai Intervening. Jurnal Riset Manajemen Sains Indonesia, 10(2), 337-355. https://doi.org/doi.org/10.21009/JRMSI.010.2.06

Sa'adah; Jahizatus. (2011). Pengaruh Service Quality terhadap Satisfaction, Trust, dan Loyalitas dalam Membentuk Word of Mouth (Studi pada Resto di Kota Tuban). Universitas Brawijaya.

Shidiq, A. M. N., \& Widodo, A. (2018). Green Product Purchase Intention: Impact of Knowledge and Green Attitude Minat Pembelian Produk Ramah Lingkungan: Dampak Pengetahuan dan Sikap Berwawasan Lingkungan. Jurnal Sekretaris \& Administrasi Bisnis, II(2), 60-73.

Sidharta, I., \& Suzanto, B. (2015). Pengaruh Kepuasan Transaksi Online Shopping dan Kepercayaan Konsumen Terhadap Sikap Serta Perilaku Konsumen Pada E-Commerce. Jurnal Computech \& Bisnis, 9(1), 23-36.

Silaen, E., \& Prabawani, B. (2019). PERSEPSI MANFAAT SERTA PROMOSI TERHADAP MINAT BELI ULANG SALDO E-WALLET OVO. 1-9. 
Sindhu Singh, R. . S. (2018). Predicting the Intention to Use Mobile Banking in India Introduction. International Journal of Bank Marketing, 36 No. 2, 357-378.

Sugara, A., \& Dewantara, R. Y. (2017). Analisis Kepercayaan Dan Kepuasan Terhadap Penggunaan Sistem Transaksi Jual Beli Online (Studi Pada Konsumen "Z"). Jurnal Administrasi Bisnis (JAB)|Vol, 52(1), 8-15. www.tekno.liputan6.com

Sugiyono. (2019). Metode Penelitian Kuantitatif, Kualitatif, dan R\&D - MPKK (2nd ed., Vol. 1). Alfabeta.

Suhendro, D. (2017). Pengaruh Kualitas Sistem, Kualitas Informasi, Kualitas Pelayanan Dan Ekspektasi Kinerja Terhadap Kepuasan Pengguna Dalam Penerapan Sistem Teknologi Informasi Pada Koperasi Di Kota Pematangsiantar. Jurasik (Jurnal Riset Sistem Informasi Dan Teknik Informatika), 1(1), 33. https://doi.org/10.30645/jurasik.v1i1.6

Sujadi, E. P. S. (2010). E-banking: Urgensi aspek trust di era e-service. Seminar Nasional Informatika, ISSN 1979-(semnasIF), 302-311.

Sulistiyarini, S. (2012). Pengaruh Minat Individu Terhadap Penggunaan Mobile Banking: Model Kombinasi Technology Acceptance Model (TAM) Dan Theory Of Planned Behavior (TPB). Jurnal Ilmiah Mahasiswa FEB, 1(2), 1689-1699.

Susanti, A. (2015). Pengaruh Persepsi Kegunaan, Persepsi Kemudahan, Persepsi Risiko dan Persepsi Kepercayaan Terhadap Minat Menggunakan Mobile Banking. IAIN Surakarta, 13(3), 1576-1580.

Teo, T., Zhou, M., Wai Fan, A. C., \& Huang, F. (2019). Factors that Influence University Students' Intention to Use Moodle: A Study in Macau. Educational Technology Research and Development, 67, 749-766.

To, W.-M., Lee, P. K. C., Lu, J., Wang, J., Yang, Y., \& Yu, Q. (2019). What Motivates Chinese Young Adults to Use mHealth? Healthcare, 7(4), 156. https://doi.org/10.3390/healthcare7040156

Ulya, A. (2013). Pengaruh Kualitas Pelayanan Inti dan Periferal Terhadap Kepuasan Konsumen Dalam Meningkatkan Minat Menggunakan Ulang. Universitas Diponegoro.

Ulya, F. N. (2019, August 19). Survei: 84,4 Persen Masyarakat Puas dengan Layanan Kesehatan Digital. Kompas.Com.

Valentina, R. A. N. (2020). Pengaruh E-Satisfaction Terhadap E-Loyalty Dengan Trust Sebagai Variable Intervening Pada Aplikasi Fintech OVO. Jurnal Strategi Pemasaran, 7(1), 8.

Wakhida, U. I., \& Sanaji. (2020). Peran Perceived Usefulness dan Perceived Risk Sebagai Variabel Pemediasi Pada Pengaruh Perceived Ease of Use dan Ewom Negatif Terhadap Niat Pembelian Para Pengguna Aplikasi Layanan Kesehatan Halodoc. 8(1989).

Wang, Z., Li, H., \& James, S. (2016). Factors Influencing Usage of Third Party Mobile Payment Services in China: An Empirical Study. 1-49.

Wiwoho, G. (2019). Pengaruh Perceived Usefulness dan Perceived Ease of Use Terhadap Customer Satisfaction dan Repurchase Intention Penggunaan Aplikasi OVO. Media Pengkajian Manajemen Dan Akuntansi, 18(1), 53-61. https://doi.org/https://doi.org/10.32639/fokusbisnis.v18i1.530

Yogananda, A. S. (2017). Pengaruh Persepsi Manfaat, Persepsi Kemudahan Penggunaan, Kepercayaan dan Persepsi Resiko Terhadap Minat untuk Menggunakan Instrumen Uang Elektronik. Semarang, Universitas Diponogoro.

Zagita, T. C., Handayani, P. W., \& Budi, N. F. A. (2019). Analysis of Factors Affecting the Loyalty of Using Online Health Services : Case Study of Alodokter. 279-284. 
Zhao, J., \& Wang, J. (2020). Health advertising on short-video social media: A study on user attitudes based on the extended technology acceptance model. International Journal of Environmental Research and Public Health, 17(5), 1-21. https://doi.org/10.3390/ijerph17051501 


\section{Lampiran 1. Karakteristik Responden}

\begin{tabular}{|c|c|c|c|c|}
\hline No. & Kategori & Sub-Kategori & Jumlah Responden & Presentase \\
\hline \multirow[t]{8}{*}{1.} & Usia & $16-20$ & 57 & $28,3 \%$ \\
\hline & & $21-25$ & 117 & $58,2 \%$ \\
\hline & & $26-30$ & 13 & $6,4 \%$ \\
\hline & & $31-35$ & 2 & $1 \%$ \\
\hline & & $36-40$ & 5 & $2,4 \%$ \\
\hline & & $41-45$ & 3 & $1,4 \%$ \\
\hline & & $46-50$ & 3 & $1,4 \%$ \\
\hline & & $51-55$ & 1 & $0,5 \%$ \\
\hline \multirow[t]{2}{*}{2.} & Jenis Kelamin & Pria & 127 & $63,1 \%$ \\
\hline & & Wanita & 74 & $36,8 \%$ \\
\hline \multirow[t]{6}{*}{3.} & Pekerjaan & Pelajar/Mahasiswa & 155 & $77,1 \%$ \\
\hline & & Ibu Rumah Tangga & 5 & $2,5 \%$ \\
\hline & & Karyawan Swasta & 31 & $15,4 \%$ \\
\hline & & PNS & 2 & $1 \%$ \\
\hline & & Wiraswasta & 5 & $2,5 \%$ \\
\hline & & Lainnya & 3 & $1,5 \%$ \\
\hline \multirow[t]{4}{*}{4.} & & Satu Bulan & 28 & $13,93 \%$ \\
\hline & Terakhir Kali & Tiga Minggu & 137 & $68,15 \%$ \\
\hline & Menggunakan Aplikasi & Satu Minggu & 25 & $12,43 \%$ \\
\hline & & Dua-Tiga Hari & 11 & $5,47 \%$ \\
\hline \multirow[t]{10}{*}{5.} & Fitur yang biasa & Dokter Umum & 73 & $36,31 \%$ \\
\hline & diakses & Informasi Seputar Covid-19 & 44 & $21,89 \%$ \\
\hline & & $\begin{array}{l}\text { Informasi Apotek atau Toko } \\
\text { Kesehatan Terdekat }\end{array}$ & 24 & $11,94 \%$ \\
\hline & & Artikel Kesehatan & 19 & $9,45 \%$ \\
\hline & & Dokter Spesialis Kulit & 16 & $7,96 \%$ \\
\hline & & $\begin{array}{l}\text { Informasi Rumah Sakit Terdekat } \\
\text { Dokter Gigi }\end{array}$ & 11 & $5,47 \%$ \\
\hline & & Dokter Penyakit Dalam & 7 & $3,48 \%$ \\
\hline & & Psikolog Klinis & 3 & $1,49 \%$ \\
\hline & & Dokter Hewan & 2 & $1 \%$ \\
\hline & & & 2 & $1 \%$ \\
\hline
\end{tabular}

Sumber: Data Primer yang Diolah, 2021 
Lampiran 2. Uji Validitas Variabel Perceived Usefulness

\begin{tabular}{|c|c|c|c|}
\hline Variabel & Indlkator & Loading Factor & Keterangan \\
\hline \multirow[t]{18}{*}{ Perceived Usefulness } & PU1 & 0,78 & Valid \\
\hline & PU2 & 0,78 & Valid \\
\hline & PU3 & 0,72 & Valid \\
\hline & PU4 & 0,77 & Valid \\
\hline & PU5 & 0,73 & Valid \\
\hline & PU6 & 0,78 & Valid \\
\hline & PU7 & 0,71 & Valid \\
\hline & PU8 & 0,72 & Valid \\
\hline & PU9 & 0,70 & Valid \\
\hline & PU10 & 0,78 & Valid \\
\hline & PU11 & 0,75 & Valid \\
\hline & PU12 & 0,75 & Valid \\
\hline & PU13 & 0,78 & Valid \\
\hline & PU14 & 0,78 & Valid \\
\hline & PU15 & 0,74 & Valid \\
\hline & PU16 & 0,75 & Valid \\
\hline & PU17 & 0,72 & Valid \\
\hline & PU18 & 0,72 & Valid \\
\hline \multirow[t]{12}{*}{ Perceived Ease of Use } & PEOU1 & 0,85 & Valid \\
\hline & PEOU2 & 0,83 & Valid \\
\hline & PEOU3 & 0,84 & Valid \\
\hline & PEOU4 & 0,75 & Valid \\
\hline & PEOU5 & 0,75 & Valid \\
\hline & PEOU6 & 0,86 & Valid \\
\hline & PEOU7 & 0,74 & Valid \\
\hline & PEOU8 & 0,78 & Valid \\
\hline & PEOU9 & 0,77 & Valid \\
\hline & PEOU10 & 0,76 & Valid \\
\hline & PEOU11 & 0,73 & Valid \\
\hline & PEOU12 & 0,73 & Valid \\
\hline \multirow[t]{10}{*}{ Trust in Applications } & TRST1 & 0,77 & Valid \\
\hline & TRST2 & 0,78 & Valid \\
\hline & TRST3 & 0,72 & Valid \\
\hline & TRST4 & 0,85 & Valid \\
\hline & TRST5 & 0,84 & Valid \\
\hline & TRST6 & 0,85 & Valid \\
\hline & TRST7 & 0,78 & Valid \\
\hline & TRST8 & 0,88 & Valid \\
\hline & TRST9 & 0,84 & Valid \\
\hline & TRST10 & 0,78 & Valid \\
\hline \multirow[t]{9}{*}{ Satisfaction } & STS1 & 0,84 & Valid \\
\hline & STS2 & 0,80 & Valid \\
\hline & STS3 & 0,76 & Valid \\
\hline & STS4 & 0,72 & Valid \\
\hline & STS5 & 0,76 & Valid \\
\hline & STS6 & 0,85 & Valid \\
\hline & STS7 & 0,76 & Valid \\
\hline & STS8 & 0,70 & Valid \\
\hline & STS9 & 0,84 & Valid \\
\hline Continuance Usage & $\mathrm{RI} 1$ & 0,88 & Valid \\
\hline \multirow[t]{4}{*}{ Intention } & $\mathrm{R} / 2$ & 0,78 & Valid \\
\hline & RI3 & 0,79 & Valid \\
\hline & RI4 & 0,83 & Valid \\
\hline & RI5 & 0,82 & Valid \\
\hline
\end{tabular}


Volume 8, No 1 (150-166), 2021 